\title{
HERDENKING VAN DIE HERVORMING ${ }^{1}$ )
}

Op 31 Oktober 1517 het die Augustynermonnik Martin Luther 'n beslissende stap geneem. Hoewel die vasspyker van sy 95 stellings aan die deur van die slotkapel te Wittenberg op dáárdie oomblik nie deur homself as die begin van 'n kerkhervormingsprogram bedoel is nie, het 31 Oktober 1517 tog 'n datum van beslissende betekenis geword. Want in dié 95 stellings is van die grondliggende stellings van die kerkhervorming geformuleer en die beginsels wat dáár die lig sien het in die volgende eeue 'n altyd-belangrike rol bly speel. Hierdie sestiende Eeuse her-vorming van die Kerk was 'n magtige geestelike beweging wat die kerklike, maatskaplike en persoonlike lewe van 'n groot deel van Europa vernuwe én verander het. As nasate van die Europese volke wat deur dié beweging beslissend beïnvloed is en wie se geestesinhoud deur die Kerkhervorming mede bepaal is, wil ons vanaand in dankbaarheid die groot manne van die sestiende Eeu gedenk. Die vrugte van die boom wat deur Luther, Calvyn en hulle medewerkers geplant is, word ook deur ons, hier in Suid-Afrika, vandag nog gepluk.

Waar ons vanaand as Afrikaners die kerkhervorming gedenk, kan ons dit doen omdat on belangrikste stamland Nederland van wie ons die seëninge van die hervorming ontvang het, self so geweldig veel aan die kerkhervorming te danke het. Want die eeu van die hervorming is ook die eeu van Nederland se nasionale wording. En ten opsigte van die hervorming van die Nederlandse kerk was Luther ook daar die groot profetiese gestalte wat die woord gespreek het wat aan dié beweging geboorte gegee het. Tog het op die duur geblyk dat Luther nie die belangrikste invloed in die Nederlandse kerkhervorming sou wees nie. Sy denke, sy geskrifte het wel die eerste stoot daartoe gegee want sy stigtelike boeke is baie in Nederland gelees en sy Bybelvertaling wat in Duitsland so 'n geweldige invloed gehad het, is daar ook bestudeer. Maar in Nederland het Luther tog in hoofsaak alleen maar suggererend gewerk maar hy is nié nagevolg nie. ${ }^{2}$ ).

Aanvanklik het die gedagtes van die kerkhervorming in Nederland alleen in die kringe van die gegoede burgery wat of met Erasmus of met die prediking van die Augustynermonikke in aanraking was, invloed uitgeoefen. Maar vanaf die vyftigerjare van die sestiende Eeu ontvang die hervormingsbeweging in Nederland, wat dan reeds die Anabaptistiese en Sakramentariese strominge ken, die invloed van die grootste van die kerkhervormers, Johannes Calvyn. Eers onder die invloed van die calvinistiese hervormingsbeweging, wat al die ander kerkhervormende bewegings in Nederland oorskadu, kry die kerkhervorming in Nederland omvang en betekenis. Mét die opkoms van die calvinisme in Nederland

1) Lesing gehou vir 'n kongres van die Ring van Johannesburg te Cottesloe, 31 Oktober 1960.

2) J. W. Pont, Geschiedenis van het Lutheranisme in de Nederlanden tot 1618, Haarlem 1911, blz. 285-287. 
gaan die oplewing op nasionale gebied gepaard en nie net die her-vorming van die Kerk nie, maar ook die vryheidstryd teen die Spaanse owerheid kry ' $n$ belangrike stimulus en rigting vanweë die calvinisme. Die invloed van Calvyn, Bullinger en Zwingli is dus nie net beperk tot die Kerk nie, maar dit het die hele volkslewe en die geestesinhoud van die protestantse volksdeel mede bepaal ${ }^{3}$ ).

As ons nou die Hervorming gedenk doen ons dit as calviniste, want uit die Nederlandse hervormde Kerk het ons Afrikaanse kerke gegroei en aan die spesifiek Nederlandse kerkhervorming dank ons ons kerklike Belydenisskrifte en ons kerklike formuliere. Ons gedenk egter die Hervorming nié sonder inagneming van manne soos Luther en Zwingli en hulle arbeid nie. Want hoewel ons nie altyd uiterlik-sigbaar as Kerk die kentekens dra van die kerklik-organisatoriese beginsels soos hulle dit uiteengesit het nie, weet ons tog as mede-erfgename van die sestiende Eeuse hervorming van 'n eenheid in die geloof wat selfs die sigbaarorganisatoriese geskeidenheid en die konfessionele verskille kan transcendeer $\left.{ }^{4}\right)$. As daar dus sprake is van die sestiende Eeuse kerkhervorming dan waardeer ons dit inderdaad in die eerste plek as calviniste maar nie sonder die besef dat die belangrike beginsels van die Hervorming nie aan die Lutheranisme of die Calvinisme alléén toegeskryf kan word nie maar dat dit die gevolg is van 'n gemeenskaplike nuwe verstaan en 'n nuwe gehoorsaanheid aan die Woord van God alleen soos dit aan Martin Luther en Johannes Calvyn en hulle medewerkers in die sestiende Eeu gegee is.

Die kerkhervorming van die sestiende Eeu is in die eerste plek 'n geestelike ommekeer en 'n godsdienstige vernuwing. Die hervorming kan ook eerder as 'n godsdienstig-geestelike beweging waardeer word as 'n puur binne-kerklike beweging. Die Hervorming het immer 'n blywende en steeds voortgaande invloed op Wes-Europa en die afstammelinge van Wes-Europese protestantse christendom in ander wêrelddele nie net ten opsigte van hulle kerklik-teologiese opvattings nie maar ook ten opsigte van die beginsels wat op die maatskaplike, politieke, opvoedkundige en alle ander terreine van die lewe van toepassing is. Die kerkhervorming kan dus nie net as 'n puur-kerklike beweging waardeer word nie. Immers die godsdiens omvat die hele mens en daarom is ' $n$ verandering of ' $n$ hervorming van die teologie of van die godsdiens nooit beperkbaar tot binne die Kerk alleen nie, dit moet die ander lewensterreine óók beroer, verander of hervorm.

Daarom is dit wel interessant om 'n oomblik vlugtig te probeer nagaan wat die nuwe is wat deur die sestiende Eeuse kerkhervorming na vore gebring is. Want hierdie nuwe in die teologie het alle terreine van die mens se lewe geraak en het aan die protestantisme 'n

3) J. Reitsma en J. Lindeboom, Geschiedenis van de Hervorming en de Hervormde Kerk der Nederlanden, Den Haag 1949, blz. $62 \mathrm{vg}$.

4) Vgl. W. Nijenhuis, Calvinus Oecumenicus, Den Haag 1959, bl. 234. 
heel eie karakter en inhoud gegee. Tog sal dit nié moontlik wees om die deurwerking van dié nuwe op die lewensterreine buite die kerklike hier in oënskou te neem nie. Dit sou ons vir hierdie geleentheid ook te ver voer.

In die poging om die nuwe aan te dui wat die kerkhervorming in die sestiende Eeu gebring het, sal ons vir 'n groot deel by Martin Luther, die Duitse kerkhervormer, stilstaan. Dit gebeur hoofsaaklik omdat Luther die nuwe van die hervorming die eerste geformuleer het en omdat Johannes Calvyn ten opsigte van die belangrike beginsels van die hervorming slegs in ' $n$ mate en deels glad nie van Luther verskil het nie ${ }^{5}$ ).

Eenvoudig is dit seker nié om die nuwe wat in die sestiende Eeu na vore gebring is, aan te dui nie. Want die Hervormers was self ook mense van hulle eie tyd wat baie van die Middeleeuse geestelike erfgoed saamgebring het in die nuwe beweging wat deur hulle optrede begin is. Daarom kan dit so maklik gebeur dat as één element uit die hervorming as dié nuwe beklemtoon word, daar later tog weer besef word dat dit nie die enigste was nie. Soms gebeur dit ook dat wat as dié nuwe van die hervorming aangedui word, reeds as beginsel deur andere vóór die hervorming geformuleer is. In die vorige Eeu is byvoorbeeld gestel dat die nuwe wat deur die Hervorming na vore gebring is hierdie twee beginsels was: die regverdiging van die sondaar deur die geloof alleen en ten tweede dat die Heilige Skrif die enigste kenbron vir die geloof en die lewe van die Kerk is ${ }^{\theta}$ ). Maar hierdie beginsels assodanig was nie nuut in dié sin dat Martin Luther dit die eerste maal in die sestiende Eeu geformuleer het nie. Want die beginsel dat die sondaar deur die geloof alleen geregverdig word, is reeds in 1512, vier jaar voordat Luther se geskrifte oor die regverdiging verskyn, so geformuleer deur die Bybelse humanis Lefèvre d'Etaples in sy Kommentaar op die Briewe van Paulus ${ }^{7}$ ). Die tweede beginsel dat die Heilige Skrif die enigste kenbron vir die geloof en lewe van die Kerk is, is reeds voor Luther geformuleer deur verskillende van die sogenaamde „voorlopers" van die hervorming ${ }^{8}$ ).

Dit is dus duidelik dat nie alles wat Martin Luther as reformatoriese beginsels geformuleer het, sommerso as die nuwe van die hervorming aangemerk kan word nie. Daarby mag ook nie vergeet word nie dat Luther 'n deur en deur kerklike mens was wat met sy optrede in die eerste plek die Kerk wou dien en die geloof wou bevorder. Hier lê terloops, ook die groot verskil tussen Luther en baie van sy latere nabootsers wat merendeels hulle eie eer en belangrikheid gedien het en nié die geloof en die Kerk nie! Die feit dat Luther 'n behoudende teoloog was, het meegebring dat hy nie sy hele Middeleeuse erfenis oorboord gegooi het nie. Inteendeel in vele opsigte het Luther nog gebonde gebly aan die

5) Vir Calvyn se waardering van Luther vergelyk sy brief van Jan. 1945 soos gesiteer by

W. F. Dankbaar, Calvijn, zijn weg en werk, Nijkerk z.j., bl. 64.

6) W. Koehler, Dagmengeschichte, Zürich 1951, Bd. I, S. 357.

7) J. Chambon, Geschiedenis ener Martelaarskerk, Goes 1951, bl. 22.

8) J. Loserth, Huss und Wiclif, München 1925, S. 187. 
Middeleeuse teologiese denke ${ }^{9}$ ). Maar daardie Middeleeuse erfenis was seker nie die bepalende in sy teologie nie want vanuit daardie Middeleeuse teologie het Luther ' $n$ besondere en 'n standhoudende vernuwing van die Kerk gebring. Tog moet ons daarmee rekening hou dat Luther in vele opsigte meer by die Middeleeue as by die moderne tyd tuishoort. Teologies, histories en ook kultuurhistories het die sogenaamde moderne tyd eerder met die agtiende Eeuse Verligting begin as met die sestiende Eeuse kerkhervorming.

Die vraag na die nuwe van die hervorming wil ek so stel: Waar is Martin Luther in sy teologiese denke anders as die teoloë van sy tyd wat binne die kring van die toomse Kerk gebly het? Wat was dit wat Luther só neerbuig, wat beroer sy lewe só dat hy in die roomse Kerk geen rus meer ken nie, maar soek en worstel vir die oplossing van sy probleme? Later skryf Luther self hieroor en sê dan ${ }^{10}$ ):

„Ek wou 'n heilige en vroom monnik wees en ek het myself met groot vroomheid vir die mis en die gebed voorberei, maar wanneer ek die vroomste was, het ek tog as twyfelaar na die altaar gegaan en as twyfelaar het ek vandaar teruggekeer. Al het ek my boetegebed opgesê, het ek nog getwyfel en as ek my boetegebed nié uitgespreek het nie, het ek andermaal getwyfel. Want ons was volkome in die waan dat ons nie kan bid en dat ons nie verhoor kan word nie as ons nie heeltemal rein en sonder sonde, soos die heiliges in die hemel, was nie.

Gedeeltelik kan Luther se geestelike stryd toegeskrywe word aan sy teologiese opleiding, want Luther het as Augustynermonnik sy belangrikste skoling in die sistematiese teologie aan die hand van die geskrifte van die Middeleeuer Willem van Occam gekry. In hierdie teologie is die onmeetlike afstand tussen die Almagtige God in die hemel en die mens op die aarde baie sterk beklemtoon. En Luther wat erns met sy sondige mens-wees gemaak het, was oorweldig deur die gedagte dat hy voor God moet lewe ${ }^{11}$ ). Hier lê die kiem van die werklik-nuwe wat Luther vanuit die Occamistiese teologie en deur sy bestudering van die Heilige Skrif na vore bring naamlik dat die lewe van die mens nié iets is wat naas God of weg van God plaasvind nie, maar dit is altyd 'n lewe vóór Gods aangesig. Hiermee het Luther nie alleen die Middeleeuse dualisme oorwin nie, maar die vir die sestiende Eeu besonder-nuwe gestel dat die mens in 'n verband met God staan, dat hy voor Gods aangesig staan en dáár moet lewe $\left.{ }^{12}\right)$. So dikwels word gestel dat die sentrale probleem waarmee

D) W. Koehler, a.a.O., S. 357.

10) Weimarer Ausgabe (hierna gesiteer as W.A.), 22, 305, 35 f. Vgl. W.A., TR., 5, 6017.

11) Roland H. Bainton, The Reformation of the Sixteenth Century, London 1957, p. 28: Luther was all the more panic-stricken because he entertained so exalted and so vivid a concept of God, the majestic, the all-holy, ... without whom there can be no security and with whom so lang as man is evil there can be no peace. Attracted and repelled, exalted and devastated, Luther wrestled with the Most High.

12) Vgl. Luther se skerp kritiek op die skolastieke teologie van sy tyd: W.A., 20, 2, 327, $20 ; 40,2,327,37 ; 40,2,458,27 ; 42,294,18$. 
Luther worstel is: Hoe kry ek 'n genadige God? en dan word daaruit die konklusie getrek dat Luther se hele teologiese denke die mens as middelpunt het, dat dit vir hom gaan om sy eie siel en lewe ${ }^{13}$ ). Maar by Luther is die worsteling met hierdie vraag: Hoe kry ek 'n genadige God? juis dié weg waarlangs Luther van die mens af weggevoer word na God toe. Want Luther se oplossing vir die probleem is dat die mens alleen 'n genadige God ,kry”' as die mens die genade ontvang om hom geheel aan God oor te gee, Gods oordele te erken en te aanvaar en in sy menslike armoede voor God, Gods genade te aanvaar as die wonder van die tweede skepping. Die basis van die verhouding God tot mens is nou nie meer die verdienste van die mens nie, maar dit is nou die sola gratia, die sola fide wat die mens suiwer en alleen as geskenk van God „,besit”.

Juis omdat Luther dit so geweldig sterk beklemtoon dat die mens voor die aangesig van God moet lewe, daarom kan ons ook sê dat die groot verskil tussen Luther en sy roomse tydgenote dit is dat die geloofswaarhede van die Heilige Skrif vir Luther sekere werklikheid is en nie 'n reeks abstrakte, swewende, filosofiese begrippe nie. In hierdie opvatting is daar dan ook geen verskil tussen Luther en Calvyn nie. Noltensmeier stel dit as volg $\left.{ }^{14}\right)$ :

„Die Orfenbarung Gottes in seinem Wort und die Ueberordnung dieser Offenbarung über die Kirche und alle Tradition, das war das Grundanliegen, dem sich beide Reformatoren verpflichtet sahen und dem sie mit ganzer Hingabe dienten."

Deur die optrede van Luther, deur sy geskrifte kom daar 'n ontwaking van die bewussyn van die werklikheid van God, van die grootheid en die genade van God, van die werklikheid daarvan dat die Heilige Gees „,tot ons eiendom (wil) maak wat ons in Christus besit ${ }^{15}$.) Die groot wins van Luther se optrede is dat God die Almagtige weer geglo word nié as 'n gedagte of ' $n$ leer of as die eindresultaat van die mens se denke nie, maar as die lewende God, die Waaragtige wat is en tot in ewigheid sal wees.

Hierdie gedagte dat die mens met sy lewe-in-die-totaliteit-daarvan voor Gods aangesig staan, is die agtergrond van Luther se hele teologie ${ }^{16}$ ) en hierdie werklikheid is die agtergrond van die kerkhervormerde werk van die sestiende Eeuse protestante. God het hulle gevind deur sy Woord en Gees en hulle het God gevind, hulle is aangegryp deur die één, Almagtige wat die gelowige dra, vrede en krag gee, wat die sekerheid van die vergewing van die sonde vanweë die Kruis van Jesus Christus gee, wat die gelowige tot ' $n$ nuwe lewe roep en tot ' $n$ lewe van diens besiel. Nieteenstaande die feit dat die verskillende leidinggéwende hervormers

13) Hierdie misverstand kan veral by die roomse beoordelaars van Luther opgemerk word Vgl. hier K. A. Meissinger, Der Katholische Luther, Leipzig 1952, S.92 f.

14) $H$. Noltensmeier, Reformatorische Einheit, Graz-Köln 1953, S. 95. Vgl. John Calvin, Tracts and Treatises on the Reformation of the Church, trans. H. Beveridge, Edinburgh 1958, Vol. I, p. 61 f.

15) Doopformulier.

$\left.{ }^{16}\right)$ J. T. Bakker, Coram Deo, Kampen 1956, p. 195-196. 
elk op sy eie manier werk en skrywe, kom ons by hulle almal, in die getuienisse van die martelare en in die belydenisse van die eenvoudige vromes hierdie sentrale tema teë: In Christus Jesus is die werklikheid van God weer aan hulle geopenbaar, deur die Woord van God het die werklikheid van Christus Jesus en sy Kruis vir die sondaar-mens wat voor Gods aangesig moet lewe, weer 'n allesbeheersende werklikheid geword. Vanuit hierdie gedagte kry die kerkhervorming sy stukrag. Nie vanuit die denke of woord van 'n mens nie, maar vanuit die openbaring van God in sy Woord. Dáárom ontwaak daar 'n vernuwende besef, daarom kom die kerk-her-vorming tot stand.

Miskien kan ons dit ook só stel: Die hervorming is 'n her-nude ontdekking van die Evangelie. Maar nié die ontdekking van 'n nuwe Evangelie nie! Want die sestiende Eeuse hervorming staan op die bodem van die historiese christendom - en die christendom kan alleen lewe vanuit die Evangelie van die Kruis en die Opstanding van Jesus Christus. Want as dit nie die middelpunt is nie, is dit nie meer christendom nie. Johannes Calvyn stel dit in sy brief Aan Koning Frans I van Frankryk, 'n begeleidende skrywe by sy Institusie van 1536 as volg:

„In die eerste plek, wanneer hulle (die teenstanders van die Hervorming) dit 'n nuwe leer noem, is hulle besig om God swaar te beledig, want sy Heilige Woord verdien dit nie om van nuwigheid beskuldig te word nie. Dat dit egter vir hulle nuut is, vir wie ook Christus en die Evangelie nuut is, dit betwyfel ek allermins. Maar hulle wat weet dat die prediking van Paulus, dat Jesus Christus terwille van ons sonde gesterwe het en terwille van ons regverdigmaking opgewek is (Rom. 4:25) oud is, sal by ons niks nuuts aantref nie."

Dit is werklik 'n misvatting om te dink, soos soms wel gebeur, dat die hervorming in die sestiende Eeu 'n paar leerstukke, sommige instellings en die ergste dwalings van die roomse Kerk verwyder het en in die plek daarvan beter leerstukke en instellings gegee het. Dit het die roomse Kerk immers self by die konsilie van Trente gedoen. Só oppervlakkig was die werk van die hervormers beslis nie ${ }^{17}$ ). Martin Luther het 'n nuwe beginsel na vore gebring, 'n beginsel wat ontleen is aan 'n nuwe, 'n beter verstaan van die Evangelie, dié Evangelie wat 'n inhoud het wat nooit oud word nie omdat dit die lewende Woord van God is. En laat ons goed onthou, Luther en sy hervormende tydgenote het hulle nié van die verlede losgeruk nie, hulle werk was nie rewolusionêr nie maar hervormend.

Dié vernuwende gedagte wat Martin Luther as gevolg van sy nuwe verstaan van die ou Evangelie na vore bring word in die leerstuk van die algemene priesterskap van die gelowiges saamgevat. Dit is 'n leerstuk wat hy in 1519 die eerste maal in sy dispuut met Johannes Eck te Leipzig, stel. Interessant is dit om daarop te let dat die negentiende Eeuse teoloog

17) H. Fausel, D. Martin Luther, Stuttgart 1955, S. 178-179. 
F.E.D. Schleiermacher êrens in 'n poging om die verskil tussen die protestantisme en die rooms-katolicisme te definieer, gestel het:

„Die protestantisme maak die verhouding van die enkeling tot die Kerk afhanklik van sy verhouding tot Christus. Die (rooms-) katholicisme omgekeerd maak die verhouding van die enkeling tot Christus afhanklik van sy verhouding tot die Kerk."

Op hierdie punt kan ek volkome saamstem. Want die enkeling, die ,gewone gelowige" is in die Middeleeuse, roomse Kerk heeltemal op die agtergrond gedruk. Op die voorgrond staan die gewyde organisasie wat nie alleen die Koninkryk van God verteenwoordig nie, maar ook pretendeer om dit te wees. Om tot daardie sigbare organisasie te behoort, dit is die enigste wat van die ",gewone gelowige" verwag word want daardie uiterlik-sigbare organisasie van die roomse Kerk is nie alleen, volgens hulle opvatting, die draer van die lewe nie, maar ook van die waarheid, die bemiddelaar van die ewige heil van die mensekind.

Teenoor hierdie roomse opvatting stel Luther die leer van die algemene priesterskap van die gelowige, 'n leer wat hy in die jare 1519-1520 ontwikkel. Omdat Luther so diep bewus is van sy persoonlike staan voor God, omdat hy besef dat hy as sondaar-mens wat sélf vir sy sonde verantwoordelik is voor die almagtige God staan, dáárom kan Luther geen rus, geen vrede in die roomse Kerk vind nie. Terselfdertyd is Luther se geestelike worsteling vir sy kloostergenote ook onverstaanbaar. Want juis die lidmaatskap van die roomse Kerk, dié Kerk wat pretendeer om die saligheid van sy lidmate wat stiptelik volgens die aanwysing van die Kerk handel, te waarborg, is vir Luther se tydgenote die oplossing van sy probleem. Eers nadat Luther deur sy sorgvuldige, aanhoudende bestudering van die Heilige Skrif die werklike oplossing vind, kry hy ook werklik vrede. Want dan word dit vir Luther duidelik dat hy as sondaar-mens voor die angesig van die regverdige God staan maar dat in Jesus Christus die regverdig-oordelende God die sondaar-mens genadig is. Maar hierdie verhouding van God tot mens kan nié deur die Kerk of die priester bemiddel word nie omdat dit 'n intens-persoonlike verhouding is. Daarom stel Luther dit ook pertinent ${ }^{18}$ ).

„Bedink tog dat God met $u$ bemoeienis maak en dat $u$ saligheid rus op wat God in u werk. Niemand moet hom op die werk van ander verlaat nie, maar aandagtig op homself let én op God, asof hy en God alleen in die hemel en op aarde is, asof God met niemand anders as net met hom te make het nie."

Dáárom gaan dit vir Luther, want baat die skoonste en beste hom as hy geen vrede met God het nie? Om hierdie rede vertaal Luther Psalm

18) Vgl. ook W.A., TR., 2, 1652: Glaube ist nicht eine Qualitas, Geschicklichkeit, das ist ein menschlicher Gedanke nach der Vernuft, derselbige taug an ihm selbs nichtes; sondern das ist der Glaube, der christum, im Wort fürgetragen und verwickelt, ergreift durch Wirkung des heiligen Geistes, der das Herz, so durchs Gesetz erschreckt ist und Gottes Zorn wider die Sünde recht fühlet, mit dem Evangelio widerum aufrichtet und tröstet. 
73:25 ook: ,As ek U maar het, dan vra ek nie na hemel of aarde nie" ${ }^{19}$ ) Hierdie sterk beklemtoning van die persoonlike geloof wat as 'n gawe van God aanvaar word, hierdie persoonlike betrokkenheid op die Kruis van Jesus Christus, is die agtergrond en inhoud van Luther se leer van die algemene priesterskap van die gelowiges. Daarom verwerp Luther ook die roomse priesterkerk waar die priester as bemiddelende tussenpersoon tussen die gelowige en God, die Almagtige staan. Nóg die priester wat pretendeer om ten behoewe van die mens voor God in te tree, nog die Kerk wat pretendeer om die mens tot God te bring, nog die sakrament wat as genademiddel in die Kerk gebruik word, kan die sondaar-mens in die persoonlike verhouding met God bring nie. Alleen as die sondige mens die genadegawe van die geloof uit Gods hand ontvang het, alleen dan is daar 'n direkte verhouding met God deur die geloof in Jesus Christus. Alleen dan is daar ook sekerheid van die vergewing van die sonde en die krag tot oorwinning deur Jesus Christus. Alleen dan kan die mens lewe uit die vreugde van kind-van-God te wees, dan weet die mens ook van dit wat verbeur was, maar wat in Christus weer as genadegawe geskenk word, van die genadegawe van God wat dan ook ,,besit" van die mens genoem kan word. In hierdie persoonlike geloof is almal gelyk voor God omdat almal gelyk sondaar is. Daarom sê Luther dat die gelowiges ook almal gelykelik priesters is ${ }^{20}$ ). En die genadegawe van die geloof in Jesus Christus ontvang die sondaar-mens alléén en direk van God self, en nié deur die bemiddeling van enigiemand nie.

Hierdie leerstuk van die algemene priesterskap van die gelowige het vir Luther verreikende gevolge. In sy verskillende geskrifte van die jare 1519-1520 trek Luther die konsekwensies van hierdie waarheid en die een pilaar na die ander, waarop die roomse Kerk rus, word deur hom omgewerp. Die anspraak van die pous om die sigbare hoof van die roomse Kerk te wees (Von Papsttum zu Rom wider den hochberühmten Romanisten zu Leipzig), die aanspraak van die hiërargie om die christengemeente te lei en hulle lewe te reël (An den christlichen Adel deutscher Nation), die aanspraak van die priesterkerk om deur middel van kerklike instellings die mens se lewe welgevallig voor God te maak (de captivitate Babylonica ecclesiae), word almal deur Luther afgewys. Ook die reg van die Kerk verloor sy krag vir Luther en daarom verbrand hy die pouslike banbul en die Corpus Iuris Canonici en te Worms verklaar hy dat hy geen ander woord sal gehoorsaam as net die Woord van God wat hy in die Skrif beluister nie.

Teenoor die roomse Kerk met sy menseheerskappy getuig Luther van die ware Kerk waar Christus alléén regeer, waar geen heerskappy gevoer word nie maar waar in liefde teenoor God en die naaste alleen die begrip diens gebruik word. Hierdie Kerk wat Luther op die leer van die

19) Vg. ook W.A., TR., 2, 2763 b.

20) W.A., 6,566, 27 f: omnes nos aequaliter esse sacerdotes, hoc est, eandem in verbo et sacramento quocunque habere potestatem, verum non licere quenquam hac ipsa uti insi consensu communitatis aut vocatione maioris. 
algemene priesterskap van die gelowiges bou, is na sy wese nie in die eerste plek 'n sigbare organisasie in die wêreld nie. Want terwyl die enigste hoof van die Kerk, Jesus Christus, nou nog in die hemele is en omdat die besit van die Kerk suiwer geestelik is, daarom kan diegene wat tot die ware Kerk behoort nié in die eerste plek sigbaar-georganiseerde versameling wees nie $^{21}$ ).

Ook Johannes Calvyn wat ten opsigte van die leer van die algemene priesterskap van die gelowiges heeltemal met Luther saamstem, weet dat die ware Kerk ook onsigbaar is. In sy reeds genoemde brief aan koning Frans I sê Calvyn byvoorbeeld:

„Ons voer op die oomblik ock geen stryd teen die Kerk nie, terwyl ons immers die een God en Christus die Heer in eenstemmigheid, met die ganse volk van gelowiges eer en aanbid, soos Hy altyd deur alle vromes aanbid is. Maar ons teenstanders dwaal nie weinig van die waarheid af nie as hulle niks anders as Kerk erken as dit wat hulle met hulle liggaamlike oë aanskou en as hulle probeer om die Kerk met grense te omsluit waarin die Kerk geensins ingesluit is nie, Dit is die hoofpunte waaroor ons verskil gaan: dat hulle in die eerste plek beweer dat die Kerk altyd homself vertoon en sigbaar is in 'n uiterlike gestalte en ten tweede dat hulle hierdie gestalte vasstel in die roomse stoel en in die hiërargie van sy biskoppe. Ons daarteenoor stel dat die Kerk kan bestaan ook sonder ' $n$ sigbare gestalte en dat sy gestalte nie deur die uiterlike glans nie, wat hulle so dwaaslik bewonder, maar deur iets heeltemal anders gekenmerk word, naamlik deur die suiwere prediking van Gods Woord en die wettige bediening van die sakramente. Hulle (die teenstanders) brom wanneer die Kerk nie altyd met die vinger aangewys kan word nie."

Hoewel die ware Kerk volgens Luther en Calvyn onsigbaar is, hoef mens egter nie daaraan te twyfel of die Kerk werklik bestaan nie. Want hoe kan Christus koning wees as Hy nie 'n koninkryk het waaroor Hy regeer nie ${ }^{22}$ ). Daarom, waar Gods Woord verkondig word, daar moet, omdat dit Gods Woord is, 'n steeds groeiende skare van gelowiges wees ${ }^{23}$ ). Hoewel die Kerk dus nie in die eerste plek vir die vleeslike oog sigbaar is nie, met die geestelike oog, met ander woorde deur die geloof, kan dit wél gesien word ${ }^{\mathbf{2 4}}$ ). Want die geloof sien die uitbreidende mag van Christus, hoewel dit in die nederigheid vir die ongelowige verborge bly, die geloof

21) As die belangrikste bewysplase dat Luther inderdaad van 'n onsigbare Kerk spreek, kan genoem word: W.A., 3, 183, $24 \mathrm{f} ; 3,203,22 ; 4,81,12 ; 4,107,12 ; 4,450,39 \mathrm{f}$. Dit is wel waar dat Luther die woord unsichtbar of die woord unsichtlich nie baie van die Kerk gebruik nie. Maar vir Luther bekken die woord geestelik dieselfde as onsigbaar, en geestelik het Luther die Kerk baie genoem.

$22)$ W.A., 3, 259, 20;3, 578, 29; 4, 85, 5 .

23) W.A., $4,183,18$.

24) W.A., 4, 189, $17 \mathrm{f}$. 
sien hoe die Kerk wat deur Christus regeer word, hoewel dit hier nog 'n stryd voer, reeds triomfeer ${ }^{25}$ ).

Hierdie Kerk is egter nie net onsigbaar nie, maar dit is ook ' $n$ werklike en sigbare gemeenskap, ja die enigste ware gemeenskap vanweë die innerlike gemeenskap in die geloof. Want daar is geen uiterlike dwang wat die lidmate bymekaar hou nie ${ }^{26}$ ). Hoewel die gelowiges dikwels van mekaar geskei is na tyd en ruimte en nie eers almal van mekaar weet nie, bly hulle 'n eenheid. Want die eenheid vind die gelowiges in die één Hoof, Jesus Christus met wie hulle deur die geloof almal persoonlik verbonde is, en die eenheid beoefen hulle deur die voorbede vir mekaar wat die christen se plig is. Hierdie eenheid wat onsigbaar is, maar daarom nog nie onwerklik is nie, plant hom van geslag tot geslag voort in die successio fidelium ${ }^{27}$ ).

So werk Luther se nuwe beginsel deur in die teologie want die in die geskiedenis werksame Woord van God is die basis van sy ekklesiologie, en deur die Woord van God word die onsigbare, ware Kerk verbind met die Kerk soos hy op aarde onder die mense as 'n liggaamlike versameling tog ook weer sigbaar is. Tog is dit nie twee Kerke nie maar twee maniere waarop die Heilige Skrif van die Kerk spreek.

Deur die beklemtoning van die persoonlike geloof word die kerke van die hervorming totaal anders as die roomse Kerk. Want by die hervorming sien ons gemeentes wat rondom die Kruis van Jesus Christus vergader is, rondom die Heilige Skrif wat hulle verstaan. Die gelowiges verstaan die Bybel egter nié in die eerste plek omdat hulle Hebreeus en Grieks, die grondtale van die Skrif verstaan nie, maar omdat hulle die grondtaal van die Kerk, die lewende Woord van God deur die Heilige Gees hoor en verstaan ${ }^{28}$ ).

Deur die beklemtoning van die persoonlike geloof gebeur dit nou ook dat ons in die kerke van die Hervorming hoor hoe die gemeentes hulle geloofsbelydenis uitspreek-persoonlik en gemeenskaplik. 'n Belydenis wat hulle kán uitspreek omdat hulle die werklikheid kan aanaanvaar en kan glo wat deur die eenvoudige woorde van die Belydenis uitgedruk word.

Deur die beklemtoning van die persoonlike geloof leef die kerkevan die hervorming ook vanuit die leerstuk van die algemene priesterskap van die gelowiges, van dié gelowiges wat die ootmoed beoefen by die sekerheid van hulle geloofsoortuiging, wat die liefde tot die naaste werklik beoefen en wat ook rekening hou met die moontlikheid dat die getuienis van hulle geloof in Jesus Christus die rede vir 'n martelaarskap kán word.

25) W.A., 3, 85, 26; 3, 120, 12.

26) W.A., 3, 385, 12 f.; 3, 391, 31; 4, 233, 21; 4, 413, 26.

27) W.A., $4,165,16 ; 4,169,30$.

28) Wat natuurlik nié beteken dat die hervorming nie waardering vir die studie van die tale Hebreeus, Grieks en Latyn het nie. Vgl. hiervoor B. Gemser, Maarten Luther oor hoe noodsaaklik dit is om Latyn, Grieks en Hebreeus te leet, artikel in Hervonnde Teologiese Studies, Pretoria 1943/4, bls. 173 vg. 
Luther en Calvyn se beklemtoning van die persoonlike geloof en daaruit voortvloeiend die gerigtheid op die soli Deo gloria is die krag van die hervorming. Al het hierdie beklemtoning van die persoonlike geloof 'n sekere gedeeldheid tussen die kerke van die hervorming tot gevolg gehad, hinder dit in werklik nie, Want mét die hervormers weet ons en glo ons 'n eenheid-met-alle-gelowiges in Jesus Christus wat bo die sigbare uitstyg en daarom ook veel sterker kan wees as die sigbare uniformiteit van 'n roomse wêreldkerk. Hoewel toegegee moet word dat laasgenoemde vir vele in die protestantisme 'n versoeking kan word.

Voortvloeiend uit die beginsel van die algemene priesterskap van die gelowiges kom die ander groot beginsel van die hervorming naamlik die leer van die regverdiging van die sondaar uit genade deur die geloof alleen. Dit is volgens Luther dié geloofsartikel wat vir die ware Kerk van grondliggende betekenis is. Want die geloof is nie net 'n saak van die enkeling nie en kan dit ook nooit wees nie. Luther is met sy beklemtoning van die persoonlike geloof seker nié 'n religieuse egoìs nie. Inteendeel, die prediking van die regverdiging van die sondaar deur die geloof alleen, kan deur die gelowiges alleen in 'n gemeenskap-van-gelowiges beleef word ${ }^{29}$ ). Hierdie prediking van die regverdiging deur die geloof alleen het in die sestiende Eeu byna wonders gewerk!

Juis hier gaan dit ook weer om die sentrale vasstelling dat die mens voor Gods aangesig moet lewe en dat die mens alleen voor Gods aangesig kan lewe omdat die, in die verhouding van God tot mens, wesenlikbelangrike beweging dié van God na die mens toe is, ja, daar is eintlik géén ander beweging nie. Alles is uit God! God is die heilige, onkreukbaar in sy reg voor wie die sondige mens nie kan bestaan nie ... maar die oomblik wanneer die oordeel wat in hierdie belydenis lê oor die mens heengaan, dan word dit ook die begin van 'n nuwe lewe. Want God buig Hom in Christus tot die sondaar en God is dit wat om Jesus Christus ontwil die sondaar vergewe én red. Soos Calvyn dit so duidelik stel ${ }^{30}$ ):

,want ons (wat anders voor God stink) word, daar ons met Christus se heiligheid oorgiet is, omdat Hy ons met Homself aan die Vader gewy het, welbehaaglik asof ons suiwer en rein, ja selfs ook heilig was."

Om op God alleen te vertrou, om te bou op Gods genade wat in Jesus Christus die mons tegemoettree, sonder enige verdienste van die kant van die mens, dit is die geloof waarin die hervormers staan. Martin Luther is so deur die genadige God wat hy gesoek het, gevind en daarom vertaal Luther ook Rom. 3:28 ${ }^{31}$ ):

„Ons neem dus aan dat die mens geregverdig word deur die geloof alleen, sonder die werke van die wet."

20) Vgl. J. Calvyn, Institutio, II, 15, 6.

30) J. Calvyn, 1.1., II, 15, 6 .

$\left.{ }^{31}\right)$ Luther se regverdiging vir hierdie vertaling vind ons uitvoerig in W.A., 30, 2, $636 \mathrm{f}$,, $640 \mathrm{f}$. 
Hier voeg Luther die woordjie alleen in die teks in om sodoende te beklemtoon dat dit nié die mens en sy voortreflikhede is wat die heil verwerf nie, maar Gods skenkende genade in Jesus Christus wat aan die mens gee wat hy vir sy behoud nodig het.

Hierdie waarheid het op die godsdienstige lewe van die sestiende Eeu 'n groot invloed uitgeoefen. Want nou verdwyn die betekenis van al die uiterlik-godsdienstige, die aflaat en die bedevaart, die krampagtige strewe na goeie werke. Alles verdwyn wat nie gebore is uit die diep-persoonlike verhouding van God die Almagtige met die geregverdigde sondaar-mens deur Jesus Christus nie. Dit bring 'n geweldige omwenteling mee omdat nou weggedoen word met die Middeleeuse dualsime wat die wêreld aan die sonde en die duiwel uitlewer en slegs die sigbaar-organisatoriese grootheid van die Kerk aan God toesê. Heel die lewe word nou geheilig omdat die mens met sy hele lewe voor Gods aangesig moet lewe en ook sy daaglikse werk en spel word nou deel van sy diens-van-God. Want geen arbeid is heiliger as die gewone arbeid nie en geen lewe is heiliger as die lewe van die gelowige wat in hierdie wêreld besef dat hy aan God behoort nie. Daarom is daar in die kerke van die hervorming geen heilige persone en geen heilige beroepe en geen heilige dae nie want al die sondige is in Christus Jesus geheilig, behoort aan God omdat God in Jesus Christus sy eienaarskap andermaal oor alles geproklameer het. Soos Johannes Calvyn dit so duidelik stel ${ }^{32}$ ):

"Want ons, wat in onsself bevlek is, maar in Christus priesters is, offer onsself en alles wat aan ons behoort aan God en ons tree die hemelse heiligdom vry in ..."

Met hierdie Bybelse leer het die hervormde vadere nie net die kerklike lewe hervorm nie, maar ook die maatskaplike lewe. Want nie alleen is die verhouding van God tot die mens weer na die Bybelse waarheid teruggebring nie, maar ook die verhouding van die mens tot sy medemens. Die feit dat God mens geword het, is die groot Bybelse waarheid, dié Evangelie waarvandaan alle verhoundinge op hierdie aarde gekersten moet word. Dit gaan daarom dat ons nié Jesus die hervormer van die wêreld moet bely nie, maar Jesus die Seun van God wat vir die sonde van die mens gesterwe het. Want die sonde is die diepe oorsaak van al ons sonde en ellende en alleen deur die geloof in Jesus Christus kan ons daarvan verlos word om in vryheid én in die hoogste verantwoordelikheid voor God en langs ons medemens te lewe. Alleen vanuit Jesus Christus die Verlosser wat mens geword het, kan ons sonder sentimentaliteit, nugter en eerlik en gedra deur die geloof alleen die verhoudinge van mens tot mens kersten. Dit mag alleen só gedoen word en van hieruit moet ons elke ander weg, maar veral die weg van rewolusie of sedisie, afwys.

32) J. Calvyn, 1.1., II, 15, 6. 
Die derde belangrike winspunt van die sestiende Eeu wat hier genoem kan word, is die geloofsversekerdheid van die hervormers ${ }^{33}$ ). Hierdie beginsel is aan die roomse Kerk onbekend, maar by die hervormers van die sestiende Eeu vind ons hierdie sekerheid oral. Die Heidelbergse Kategismus vra heeltemal aan die begin hierdie vraag: „Wat is u enigste troos sowel in lewe as in sterwe?" en antwoord dan daarop:

„Dat ek met liggaam en siel, sowel in lewe as in sterwe nie aan myself nie, maar aan my getroue Saligmaker Jesus Christus toebehoort ..."

Of mens kan die Klein Kategismus van Martin Luther naslaan waar opgeteken staan:

„ek glo dat Jesus Christus my Heer is, dat die Heilige Gees my daagliks alle sonde vergewe, ..."

Die manne van die hervorming ken die vaste grond, die sekere fondament waarop hulle bou. Juis hierdie versekerdheid is een van die besondere karaktertrekke en erfenisse van die sestiende Eeuse hervorming van die Kerk. Hierdie geloofsversekerdheid is besonder belangrik en in sy geskrif De Servo Arbitrio stel Luther:

„.. . om nié te weet nie, om onseker te wees oor die plek van die vrye wil as die eie saligheid daarmee gemoeid is, is goddeloos. Dit is die kernvraag van die hele Evangelie. Die koning wat onvoorbereid ten stryde trek, is dwaas. Dwaas is ook die christen wat nie weet hoe hy voor God staan nie. Hier help geen vermoedens nie, hier baat alleen onwrikbare sekerheid."

Luther getuig hier van die vastheid en sekerheid van die geloof wat in God veranker is deur Jesus Christus, daardie God wat Hom geopenbaar het en wat ons alleen deur Jesus Christus kan ken. En Luther bely, met al die ander hervormers, al wat ek is en het, is en het ek deur en uit en in God.

As daar één belydenis is waar die hervormers éenstemmig is, dan is dit die belydenis van die Goddelike verkiesing soos ons dit uit die Nuwe Testament leer ken. Want daar word voortdurend die klem daarop gelê dat dit nié gaan om die mens en sy dade nie, maar alleen om God wat handelende besig is. Die geloof is nie menslike ,besit" nie, maar 'n gawe van God, die saligheid is nie 'n menslike verdienste nie, maar 'n geskenk van God-en in Christus Jesus gee God aan die mens wat hy nodig het. Hierdie sekerheid, hierdie onwrikbare vertroue op God die Heer is seker dié groot rede waarom die hervorming van die sestiende Eeu kon seëvier nieteenstaande die wrede en onmenslike vervolginge wat die roomse Kerk teen die hervorming ontketen het.

33) Vgl. J. Calvyn, 1.1. III, 2, 39. 
As ons vanaand die sestiende Eeuse kerkhervorming gedenk, dan is dit seker nie onvanpas dat daarvoor gepleit word dat ons dan vandag wéér sal gaan besin op die drie sentrale reformatoriese temas wat vanaand beklemtoon is nl. die leer van die algemene priesterskap van die gelowiges, die regverdiging van die sondaar deur die geloof alleen en die reformatoriese geloofsversekerdheid.

Terselfdertyd sal dit ook goed wees as ons vanaand nie net in eerbied en dankbaarheid die reformatoriese vadere van die sestiende Eeu gedenk nie. Laat ons tog ook dié vadere gedenk wat ons daarna in geloof en lewe voorgegaan het deur wie se geloof en lewe die reformatoriese waarheid ook aan ons van vandag oorgedra is. Die calvinistiese erfenis het nie net die vadere se kerklike opvattings nie maar ook hulle maatskaplike opvattings beslissend be-invloed. Veral is dit waar van dié vadere in ons geskiedenis wat huis en haard in die engelse Kaapkolonie verlaat het om hier in die binnelande van Suid-Afrika 'n eie kerklike en maatskaplikpolitieke patroon neer te lê en te bestendig. Hoewel hulle opvattings en van ons wat daardie opvattings vandag nog verder dra al as 'n vorm van primitive calvinism afgewys is, is hierdie opvattings geformuleer onder die beslissende invloed van die sestiende Eeuse hervorming. Hierdie hervorming het die Woord van God as die enigste bron van die waarheid vir die leer en die lewe aanvaar en nié die filosofie of een of ander menslikredelike denkrigting nie. Sou ons van vandag ly aan primitive calvinism omdat ons ook die Woord van God alleen wil beluister?

Deurdat die vadere in die vorige Eeu hier in die binneland van SuidAfrika, omring van ' $n$ woeste heidendom, vasgehou het aan die leer van die algemene priesterskap van die gelowige, is dit, na die mens gesproke, aan hulle te danke dat hier vandag 'n Afrikaanssprekende kerk is. Want hoewel hulle hierdie leerstuk miskien nie in soveel woorde geken het nie, het hulle tog daaruit geleef en die lig van die christelike geloof en die christelike beskawing en samelewingspatroon hier in heidense Afrika brandende gehou. Vir sestien jaar sonder die verkondiging van die Woord deur ' $n$ eie, vaste predikant, met slegs die mees elementêre sigbare kerklike organisasie, sonder skole en die ander hulpmiddels van 'n gereëlde maatskappy, het die vadere tog nié weggedwaal van die christelike geloof nie. Want die persoonlike geloof in God deur Jesus Christus die Heer, die persoonlike kennis van die Woord van God, soos hulle dit gehoor het uit die ou groot Statebybels, het hulle daarvoor bewaar en daartoe bymekaargehou. Met die Woord van God as die enigste lig op hulle pad, het die vadere die gevare, ontberinge en die pionierslewe in die Suid-Afrikaanse binneland getrotseer-seker in hulle geloof, vas in hulle vertroue dat hulle deur God die Heer nie verlaat is nie.

Die rigtinggéwende beginsels wat hulle gesteun en gedra het word besonder mooi in die beroemde namifes van Piet Retief, uitgereik net voor sy vertrek uit die Kaapkolonie saamgevat ${ }^{34}$ ):

a4) Grahamstown Joumal, 22.1.1837. $V_{g}$ l. ook die besonder mooi opmerkings oor Retief by B. Gemser, Vragen rondom de Patriarchenreligie, Groningen 1958, bl. 17 en 21. 
„Ons verlaat nou ons vrugbare geboorteland waar ons groot verliese gely het en gedurig ergerlike kwellings ondervind het en ons gaan 'n woeste en gevaarlike gebied in; maar ons gaan met 'n vaste vertroue op 'n alsiende, regverdige en genadige Opperwese en om Hom te vrees en nederig gehoorsaam te wees, sal steeds ons strewe wees."

En miskien is die tyd daarvoor ryp dat ons met steeds meer en meer klem sal stel dat die vadere aan hierdie beginsels nooit ontrou was nie en dat dit ons, wat ons as hulle erfgename beskou, ook nie gegee is om daaraan ontrou te wees nie.

Aan die geestelike erfgename van die reformatoriese vadere, aan die erfgename van die Voortrekkervadere se baanbrekerswerk word in hierdie era, in hierdie land groot uitdagings gestel. Die strewe om die erwe van die vadere ook aan ons kinders as 'n erfenis oor te dra, word deur 'n merkwaardige tydsgees, ook in ons eie Kerk, skerp veroordeel. Die antwoord op die uitdaging lê enersyds daarin dat ons helderder sal besef wat die hervorming van die Kerk in die sestiende Eeu beoog en bereik het. Dit lê in die ootmoedige, vashoudende en volhardende geloof in en vertroue op die Here God, onse Vader in Jesus Christus. Andersyds lê dit in 'n openlike getuienis van ons geloof in die herskeppende, genadige krag van die Woord van God wat ons nie alleen die weerbaarheid sal skenk nie maar ook die vaste vertroue op die almagtige God wat ons nié sal verlaat nie.

Persoonlike geloof, die lewe uit die genade, geloofsversekerdheid. Dit is drie van die ingrypende beginsels wat in die sestiende Eeu én daarna so ' $n$ magtige invloed uitgeoefen het. Deur hierdie beginsels is die Kerk en die lewe van die mens na die Woord van God her-vorm. 'n Voortdurende, voortgaande besinning op hierdie hervormde en hervormende beginsels sal vir ons alleen maar vrugbaar wees.

Daarby moet bedink word dat 'n verdere beginsel óók waar bly nl. reformatus quia reformandus. Dit wil sê die hervorming van die sestiende Eeu is nié 'n afgeslote saak nie, maar 'n beginsel. Immers die verleiding waarvoor die roomse Kerk beswyk het en waarteen die hervorming so kragtig getuig het, bestaan nóg! Ook vir ons bestaan die verleiding om Gods Woord te verwater of te verdun met ons flosofieë en gedagtes. Ook vir ons bestaan die versoeking om Jesus Christus die Verlosser van die sonde te vervang met 'n versuikerde, mensgemaakte ,Jesus, die hervormer van die wêreld". Ook vir ons bestaan die versoeking om te dink dat óns die Koninkryk van God met mensehande moet gaan verwerklik of gaan vasvang binne die grense van 'n sigbare, kerklike organisasie. Dié versoekings bly wesenlik bestaan want ook ons is mense, verlore in die sonde. 
Daarom, by die herinnering aan die hervorming, by die herdenking van die heldefigure van die hervorming-Johannes Calvyn, Martin Luther en ál die ander-kom ook die oproep:

As geestelike erfgename van die hervorming, as die besitters van die erfgoed van die Voortrekkervadere word ons hier en nou opgeroep om belyders van die Evangelie van Jesus Christus te wees, dié Evangelie van die genade van God!
En hierdie taak lê voor ons!
A. D. Pont.

\section{DIE BONDSBOEK EN DIE REG VAN GOSEN}

Die hedendaagse geskiedskrywer ondervind moeilikhede by sy pogings om 'n duidelike beeld van Moses as wetgewer te kry. Die tradisie skryf al die wetgewende bepalings wat ons in die boeke Exodus, Levitikus, Numeri en Deuteronomium vind, aan sy bemiddeling toe; die geskiedkundige ondersoek het egter in hierdie bepalings heelwat ontdek, wat moeilik met die tydsomstandighede van Moses in ooreenstemming gebring kan word. Gewoonlik neem die geskiedkundiges dan aan dat hierdie bepalings uit later tyd as Moses dateer, en deur die skrywers daarvan toegevoeg is aan 'n ouere wetboek, die kern van die hele Bybelse wetgewing, wat tot op Moses se dae sou teruggaan. Hierdie kern is deur party geleerdes in die sogenaamde Bondsboek, die versameling van gebooie en verbooie, regskundige beslissings en godsdientige aanwysings in Ex. $20: 22$ tot 23:33, aangewys. Die tradisie omtrent Moses as wetgewer is so sterk, nie maar net in die eerste vyf Bybelboeke nie, maar ook by die profete en later geskrifte van die Kanon, dat dit onmoontlik is om geheel en al af te sien van sy gestalte as wetgewer, soos tot ons verbasing en leedwese deur Noth in sy Geschichte Israels gedoen is. „Ihn als den Organisator und Gesetzgeber Israels zu bezeichnen, ist danach geschichtlich nicht haltbar" skrywe Noth op bl. 118 van die eerste druk van sy werk. Die gevolg is dan ook dat die Duitse geleerde daarin geslaag het om 'n boek oor die geskiedenis van ou Israel te skrywe, wat slegs op vier van sy vierhonderd bladsye die naam van Moses noem.

Noth se argumente, wat hoofsaaklik van ,ükerlieferungsgeschichtliche" aard is, kon ons nie oortuig dat Moses prakties geen rol in die geskiedenis van die ou bondsvolk gespeel het nie. Ons moet eerlik erken dat al die geleerdheid oor ,überlieferungsgeschichtliche Methode" op ons heelwat minder indruk maak as een Bybelteks, en dit nie maar net op teologiese gronde, maar ook om die eenvoudige en onweerspreeklike feit dat Bybeltekste 'n paar duisend jaar digter by die feite staan as selfs die geleerdste historikus van ons dae. Dit beteken egter nie, dat daar vir ons by die aanvaarding van Moses as die groot wetgewer van Israel geen 